\title{
PENGARUH STRATEGI HARGA DAN KUALITAS PELAYANAN TERHADAP KEPUTUSAN PEMBELIAN TIKET MASKAPAI PENERBANGAN CITILINK DI BANDARA SOETA JAKARTA
}

\author{
Hadyati Harras \\ email: hadyatiharras@gmail.com
}

\begin{abstract}
ABSTRAK
Tujuan daripenelitian ini adalah untukmengetahui pengaruh strategi harga dan kualitas pelayanan terhadap keputusan pembelian tiket maskapai penerbangan Citilink di Bandara Soeta Jakarta.Desain penelitianyang digunakandalam penyusunan penelitian ini adalah kuantitatifasosiatif kausal dengan eksplanasi (penjelasan) deskriptif. Adapun metode analisis yang digunakan adalah analisis regresi linear berganda dengan sampel sebanyak 98 dan teknik sampling yang digunakan adalah teknik Accidental Sampling.Hasiluji hipotesis berdasarkan pengujian regresi linear menunjukkan bahwaharga terbukti berpengaruh positif dan signifikan terhadap keputusan pembelian sebesar 0.510 dan t hitung 5.484 . Sedangkan kualitas pelayanan berpengaruh positif dan signifikan terhadap keputusan pembelian sebesar 0.258 dan $\mathrm{t}$ hitung 2.768. Hasil analisis regresi membuktikan terdapat pengaruh secara simultan variabel strategi harga dan kualitas pelayanan secara bersama-sama terbukti berpengaruh positif dan signifikan terhadap keputusan pembelian dengan kontribusi sebesar $47,7 \%$ sedangkan sisanya sebesar $52,3 \%$ dijelaskan oleh variabel lain di luar penelitian ini.
\end{abstract}

Kata Kunci : Strategi Harga, Kualitas Pelayanan, Keputusan Pembelian.

\section{ABSTRACT}

The purpose of this study is to determine the effect of pricing strategy and service quality on the decision to purchase airline tickets Citilink at Soeta Airport Jakarta.The research design used in the preparation of this study is quantitative causal associative with explanation descriptive. The method of analysis used is multiple linear regression analysis with a sample of 98 and the sampling technique used is the technique of Accidental Sampling. Hypothesis test results based on linear regression testing showed that the price proved to have a positive and significant effect on purchasing decisions of 0.510 and t count 5,484. While service quality have positive and significant effect to purchasing decision equal to 0,258 and t count 2,768. The result of regression analysis proves that there are simultaneous influence of price strategy and service quality variables together proved to have positive and significant effect on purchasing decision with contribution equal to $47,7 \%$ while the rest equal to $52,3 \%$ explained by other variable outside this research.

Keywords : Price strategy, Service quality, and Buying decision

\section{A. PENDAHULUAN}

Era globalisasi menciptakan dunia seakan tidak berbatas, negara yang satu dengan yang lain saling berhubungan untuk mempermudah adanya komunikasi demi terciptanya pertumbuhan dan perkembangan ekonomi dunia. Bahkan banyak perusahaan-perusahaan tidak lagi diam di satu negara tetapi mereka mulai membuka cabang-cabang mereka di negara lain. Akibat adanya hal tersebut, muncul sebuah tantangan bagi perusahaan penerbangan yang dirasakan semakin berat, baik 
penerbangan domestik maupun internasional. Belum lagi bisnis penerbangan dihadapkan dengan kebijakan-kebijakan internasional seperti deregulasi, liberalisasi, privatisasi, multilateral agreement, dan strategi aliansi yang telah mendorong munculnya megacamer yang berskala global. Bagi Citilink Indonesia, prospek usaha pada bisnis penerbangan yang dihadapi saat ini dan masa yang akan datang, mempunyai potensi yang besar untuk berkembang. Pasar yang ada di berbagai kawasan masih dapat ditumbuh kembangkan lebih lanjut, diperkirakan pasar penerbangan tumbuh sebesar kurang-lebih 5.7\% pertahun. Hal tersebut sejalan dengan pertumbuhan ekonomi yang pesat baik di dalam negeri maupun di kawasan Asia Pasifik. Namun demikian, tanpa persiapan yang matang serta penerapan strategi korporasi yang terpadu secara menyeluruh, maka Citilink Indonesia bisa jatuh di tengah-tengah maraknya persaingan industri penerbangan. Meski proteksi pemerintah masih mungkin dapat dilakukan untuk melindungi Airlines domestik, tetapi di masa yang akan datang tampaknya hal itu harus dilepaskan. Mengingat adanya desakan "open Sky" baik melalui multilateral agreement seperti GATT maupun bilateral agreement yang semakin kuat, serta pertimbangan ekonomi bahwa sumbangan dunia bisnis penerbangan kurang lebih hanya sebesar 7\% dari perekonomian secara keseluruhan. Berikut ini terlampir persaingan industri penerbangan di Indonesia:

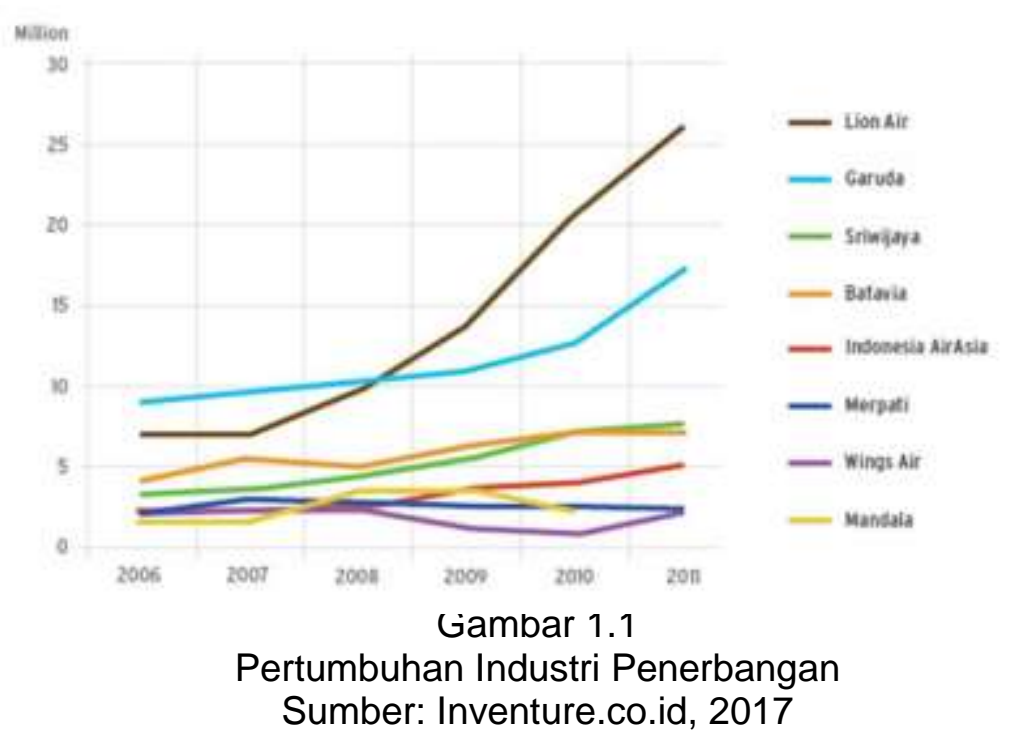


Sisi positifnya pertumbuhan penerbangan saat ini sangat menjanjikan, hal ini perlu ditanggapi serius oleh Citilink Indonesia mengingat pertumbuhan pasar semakin besar, sebagaimana terlihat di bawah ini:

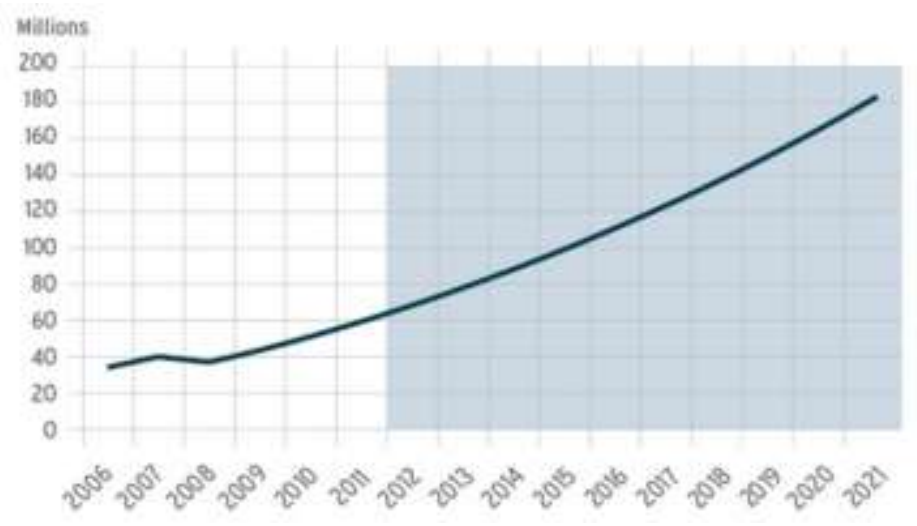

Gambar 1.2

Pertumbuhan Pasar Penerbangan di Indonesia Sumber: Inventure.co.id, 2017

PT. Citilink Indonesia (Citilink) adalah sebuah maskapai penerbangan berbiaya murah atau Low Cost Carrier (LCC) anak perusahaan dari PT. Garuda Indonesia (Persero) Tbk. Perusahaan ini berdiri tahun 2001 sebagai Unit Bisnis Strategis (UBS) dari Garuda Indonesia dan difungsikan sebagai salah satu alternatif penerbangan berbiaya murah dan tetap mengedepankan kualitas penerbangan. Berikut di bawah ini dapat dikemukakan data kualitas pelayanan pada Maskapai Penerbangan berdasarkan data Kementrian Perhubungan Republik Indonesia.

Tabel 1.1.

Kualitas Pelayanan Maskapai Penerbangan

\begin{tabular}{|l|l|c|c|c|}
\hline No & \multicolumn{1}{|c|}{ Maskapai } & $\begin{array}{c}\text { Tepat Waktu } \\
\text { (OTP) }\end{array}$ & $\begin{array}{c}\text { Keterlambatan } \\
\text { (Delay) }\end{array}$ & $\begin{array}{c}\text { Tingkat Komplain } \\
\text { Pembatalan } \\
\text { (CanceI) }\end{array}$ \\
\hline 1 & Batik Air & $91,21 \%$ & $7,30 \%$ & $1,48 \%$ \\
\hline 2 & NamAir & $90,61 \%$ & $8,16 \%$ & $0,54 \%$ \\
\hline 3 & Garuda & $85,82 \%$ & $12,02 \%$ & $2,16 \%$ \\
\hline 4 & Sriwijaya Air & $82,85 \%$ & $16,79 \%$ & $0,39 \%$ \\
\hline 5 & $\begin{array}{l}\text { Indonesia Air Asia } \\
\text { Extra }\end{array}$ & $82,40 \%$ & $17,60 \%$ & $0 \%$ \\
\hline 6 & Citilink & $80,27 \%$ & $18,66 \%$ & $1,08 \%$ \\
\hline 7 & Aviastar Mandiri & $79,57 \%$ & $20,43 \%$ & $0 \%$ \\
\hline 8 & Transnusa & $77,06 \%$ & $21,24 \%$ & $1,71 \%$ \\
\hline 9 & Indonesia Air Asia & $75,69 \%$ & $23,62 \%$ & $2,39 \%$ \\
\hline 10 & Kalstar Aviation & $74,89 \%$ & $15,81 \%$ & $9,25 \%$ \\
\hline 11 & Wings Air & $70,22 \%$ & $27,61 \%$ & $2,17 \%$ \\
\hline 12 & Lion Air & $70,06 \%$ & $29,52 \%$ & $0,42 \%$ \\
\hline 13 & Susi Air & $57,62 \%$ & $34,96 \%$ & $8,00 \%$ \\
\hline
\end{tabular}




\begin{tabular}{|c|l|c|c|c|}
\hline 14 & Travel Express & $57,67 \%$ & $33,28 \%$ & $9,05 \%$ \\
\hline 15 & Trigana Air & $48,16 \%$ & $45,74 \%$ & $6,10 \%$ \\
\hline
\end{tabular}

Sumber: Kementrian Perhubungan Republik Indonesia, 2017

Berdasarkan paparan di atas penulis tertarik untuk mengangkat sebuah judul penelitian "Pengaruh Strategi Harga Dan Kualitas Pelayanan Terhadap Keputusan Pembelian Tiket Maskapai Penerbangan Citilink Di Bandara Soeta Jakarta".

\section{B. Perumusan Masalah}

Berdasarkan latar belakang dan identifikasi masalah yang telah diuraikan di atas, maka dapat dirumuskan masalah pada penelitian ini sebagai berikut:

1. Bagaimana pengaruh strategi harga terhadap keputusan pembelian tiket maskapai penerbangan Citilink di Bandara Soeta Jakarta?

2. Bagaimana pengaruh kualitas pelayanan terhadap keputusan pembelian tiket maskapai penerbangan Citilink di Bandara Soeta Jakarta?

3. Bagaimana pengaruh strategi harga dan kualitas pelayanan secara bersama-sama terhadap keputusan pembelian tiket maskapai penerbangan Citilink di Bandara Soeta Jakarta?

\section{Tujuan Penelitian}

Adapun tujuan dari penelitian ini adalah untuk:

1. Mengetahui pengaruh strategi harga terhadap keputusan pembelian tiket maskapai penerbangan Citilink di Bandara Soeta Jakarta

2. Mengetahui pengaruh kualitas pelayanan terhadap keputusan pembelian tiket maskapai penerbangan Citilink di Bandara Soeta Jakarta

3. Mengetahui pengaruh strategi harga dan kualitas pelayanan secara bersama-sama terhadap keputusan pembelian tiket maskapai penerbangan Citilink di Bandara Soeta Jakarta.

\section{Landasan Teori}

Menurut Swastha dan Irawan (2007:12) pemasaran adalah sistem keseluruhan dari kegiatan usaha yang ditujukan untuk merencanakan, menentukan harga, mempromosikan dan mendistribusikan barang, jasa, ide kepada pasar sasaran agar dapat mencapai tujuan organisasi. 
Menurut Kotler (2005: 5) pemasaran adalah proses sosial yang dengan proses itu individu dan kelompok mendapatkan apa yang mereka butuhkan dan inginkan dengan menciptakan, menawarkan dan secara bebas mempertukarkan produk dan jasa yang bernilai dengan pihak lain.

Harga adalah jumlah uang (ditambah beberapa barang kalau mungkin) yang dibutuhkan untuk mendapatkan sejumlah kombinasi dari barang beserta pelayanannya (Swastha dan Irawan, $2007: 147$ ). Dengan kata lain harga adalah jumlah uang yang bersedia dibayar oleh pembeli dan bersedia diterima oleh penjual.

Menurut Dharmesta dan Irawan (2005:11) Istilah harga adalah jumlah uang (kemungkinan ditambah beberapa barang) yang dibutuhkan untuk memperoleh beberapa kombinasi sebuah produk dan pelayanan yang menyertainya.

Menurut Kotler dan Keller (2009:58) bahwa jasa adalah setiap tindakan atau kegiatan yang dapat ditawarkan oleh suatu pihak kepada pihak lain yang pada dasarnya tidak berwujud dan tidak menyebabkan kepemilikan kepada sesuatu, yang dapat berhubungan dengan suatu produk fisik maupun tidak.

Kualitas pelayanan menurut Hurriyati (2008:36), adalah suatu tindakan yang dilakukan untuk memenuhi kebutuhan orang lain (konsumen, pelanggan, klien, tamu, dan lain-lain) yang tingkat pemuasannya hanya dapat dirasakan oleh orang yang melayani maupun yang dilayani.

Menurut Basu Swastha dan Handoko (2008:110) mengemukakan bahwa keputusan pembelian merupakan proses dalam pembelian yang nyata, apakah membeli atau tidak.

Keputusan membeli merupakan suatu proses pengambilan keputusan akan pembelian yang mencakup penentuan apa yang akan di beli atau tidak melakukan pembelian dan keputusan itu di peroleh dari kegiatan-kegiatan sebelumnya (Dharmesta dan Irawan, 2005 : 35).

Keputusan pembelian merupakan suatu proses pengambilan keputusan akan pembelian yang mencakup penentuan apa yang akan dibeli atau tidak melakukan pembelian dan keputusan itu diperoleh dari kegiatan-kegiatan sebelumnya (Assauri, 2004:141).

\section{E. Metodologi}

Menurut Sugiyono (2012: 115) populasi adalah wilayah generalisasi yang terdiri dari obyek atau subyek yang memiliki kualitas dan karakteristik tertentu yang ditetapkan peneliti untuk dipelajari yang kemudian ditarik kesimpulannya. 
Menurut Sugiyono (2012:116) sampel dapat didefinisikan sebagai suatu bagian yang ditarik dari populasi. Riduwan dan Engkos (2011: 40) menambahkan pengertian sampel adalah bagian dari populasi yang memiliki ciri-ciri atau keadaan tertentu yang akan diteliti.

Teknik sampling yang digunakan pada penelitian adalah teknik Accidental Sampling. Sugiyono (2012:122) menjelaskan bahwa teknik insidental sampel ini merupakan suatu penentuan sampel berdasarkan kebetulan, yaitu siapa saja yang secara kebetulan bertemu dengan peneliti dapat digunakan sebagai sampel, bila dipandang orang yang kebetulan ditemui cocok sebagai sumber data.

Penelitian ini berangkat dari penelitian kuantitatif dengan eksplanasi deskriptif dan inferensial. Adapun metode analisis yang digunakan adalah analisis regresi linear berganda yang mencakup (1) analisis deskriptif, (2) uji validitas dan reliabilitas, (3) uji asumsi klasik, (4) uji hipotesis, (5) uji koefisien determinasi.

\section{F. Hasil dan Pembahasan}

Tabel 4.1. Uji Regresi Linear Berganda

\begin{tabular}{|c|c|c|c|c|}
\hline \multirow[b]{2}{*}{ Model } & \multicolumn{2}{|c|}{ Unstandardized Coefficients } & \multirow{2}{*}{$\begin{array}{c}\text { Standardized } \\
\text { Coefficients }\end{array}$} & \multirow[b]{2}{*}{$\mathrm{t}$} \\
\hline & $B$ & Std. Error & & \\
\hline $1 \quad$ (Constant) & 12.682 & 3.791 & & 3.345 \\
\hline Harga & .579 & .106 & .510 & 5.484 \\
\hline $\begin{array}{l}\text { Kualitas } \\
\text { Pelayanan }\end{array}$ & .255 & .092 & .258 & 2.768 \\
\hline
\end{tabular}

Sumber: Hasil Olah Data SPSS 22, 2017

Berdasarkan hasil olah data di atas, maka dapat dikemukakan persamaan regresi linear berganda sebagai berikut: $\mathbf{Y}=\mathbf{a}+\mathbf{b} \mathbf{1} \mathbf{x} \mathbf{1}+\mathbf{b} \mathbf{2} \times \mathbf{2}$

$\mathrm{Y}=12.682+0.510(\mathrm{X} 1)+0.258(\mathrm{X} 2)$

Tabel 4.2. Uji Koefisien Korelasi

\begin{tabular}{|l|r|r|r|}
\hline & Harga & Kualitas Pelayanan & Keputusan Pembelian \\
\hline Harga & 1 & $.615^{* *}$ & $.669^{* *}$ \\
& & .000 & .000 \\
& 98 & 98 & 98 \\
\hline Kualitas Pelayanan & $.615^{* *}$ & 1 & $.571^{* *}$ \\
& .000 & & .000 \\
& 98 & 98 & 98 \\
\hline
\end{tabular}




\begin{tabular}{|c|r|r|r|}
\hline Keputusan Pembelian & $.669^{* *}$ & $.571^{* *}$ & 1 \\
\hline \multirow{2}{*}{ Kesimpulan } & Kuat & Sedang & \\
& 98 & 98 & 98 \\
\hline
\end{tabular}

Sumber: Hasil Olah Data SPSS 22, 2017

Berdasarkan tabel di atas, dapat dikemukakan bahwa hubungan harga dengan keputusan pembelian masuk pada kategori Kuat $(0,669)$. Sedangkan hubungan kualitas pelayanan dengan keputusan pembelian masuk pada kategori Sedang $(0,571)$.

Tabel 4.3. Uji Koefisien Determinasi

Model Summary

\begin{tabular}{|l|r|r|r|r|r|}
\hline Model & $\mathrm{R}$ & \multicolumn{1}{|c|}{ R Square } & \multicolumn{1}{c|}{$\begin{array}{c}\text { Adjusted } \mathrm{R} \\
\text { Square }\end{array}$} & $\begin{array}{c}\text { Std. Error of the } \\
\text { Estimate }\end{array}$ & Durbin-Watson \\
\hline 1 & $.699^{\mathrm{a}}$ & .488 & .477 & 3.267 & 2.233 \\
\hline
\end{tabular}

a. Predictors: (Constant), Kualitas Pelayanan, Harga

b. Dependent Variable: Keputusan Pembelian

Sumber: Hasil Olah Data SPSS 22, 2017

Berdasarkan tabel tersebut di atas, bahwa nilai kontribusi variabel harga dan kualitas pelayanan sebesar 0,477 atau $47,7 \%$ terhadap keputusan pembelian, sedangkan sisanya sebesar $52,3 \%$ dijelaskan oleh variabel lain di luar penelitian ini.

Tabel 4.4. Uji Parsial (Uji t)

\section{Coefficients $^{\mathrm{a}}$}

\begin{tabular}{|c|c|c|c|c|c|}
\hline \multirow{2}{*}{ Model } & \multicolumn{2}{|l|}{ Unstandardized Coefficients } & Standardized Coefficients & & \\
\cline { 2 - 4 } & $\mathrm{B}$ & Std. Error & Beta & $\mathrm{t}$ & Sig. \\
\hline 1 (Constant) & 12.682 & 3.791 & & 3.345 & .001 \\
Harga & .579 & .106 & .510 & 5.484 & .000 \\
\hline
\end{tabular}

a. Dependent Variable: Keputusan Pembelian

Sumber: Hasil Olah Data SPSS 22, 2017

Berdasarkan tabel tersebut dapat dikemukakan sebagai berikut:

Persamaan Regresi $\quad Y=12.682+0.510$

T hitung $\quad=5.484$ 
Nilai Signifikan $\quad=0.000$

Berdasarkan keterangan tersebut di atas, maka dapat dikemukakan penjelasan sebagai berikut:

1. Bahwa nilai konstanta sebesar 12.682 memiliki arti, meskipun tidak ada pengaruh dari variabel harga, keputusan pembelian tetap memiliki nilai sebesar 12.682.

2. Variabel Harga memiliki nilai t hitung lebih besar dari t tabel $(5.484>1.984)$. Artinya harga terbukti berpengaruh positif terhadap keputusan pembelian. Dengan tafsiran, jika harga meningkat sebesar satu-satuan maka keputusan pembelian akan meningkat sebesar 0.510

3. Variabel harga memiliki nilai signifikan lebih kecil dari $0,05(0.000<0,05)$. Artinya harga berpengaruh signifikan terhadap keputusan pembelian. Dengan tafsiran, variabel harga mampu menjelaskan keputusan pembelian dengan baik dengan koefisien regresi sebesar 0.510 .

Tabel 4.5. Uji Parsial (Uji t)

Coefficients $^{\mathrm{a}}$

\begin{tabular}{|c|c|c|c|c|c|c|}
\hline \multirow[b]{2}{*}{ Model } & \multicolumn{2}{|c|}{$\begin{array}{c}\text { Unstandardized } \\
\text { Coefficients }\end{array}$} & \multirow{2}{*}{\multicolumn{2}{|c|}{$\begin{array}{c}\begin{array}{c}\text { Standardized } \\
\text { Coefficients }\end{array} \\
\text { Beta }\end{array}$}} & \multirow[b]{2}{*}{$\mathrm{t}$} & \multirow[b]{2}{*}{ Sig. } \\
\hline & B & Std. Error & & & & \\
\hline 1 (Constant) & 12.682 & 3.791 & & & 3.345 & .001 \\
\hline $\begin{array}{l}\text { Kualitas } \\
\text { Pelayanan }\end{array}$ & .255 & .092 & & .258 & 2.768 & .007 \\
\hline
\end{tabular}

a. Dependent Variable: Keputusan Pembelian

Sumber: Hasil Olah Data SPSS 22, 2017

Berdasarkan tabel tersebut dapat dikemukakan sebagai berikut:

Persamaan Regresi $\quad Y=12.682+0.258$

Thitung $\quad=2.768$

Nilai Signifikan $\quad=0.007$

Berdasarkan keterangan tersebut di atas, maka dapat dikemukakan penjelasan sebagai berikut:

1. Bahwa nilai konstanta sebesar 12.682 memiliki arti, meskipun tidak ada pengaruh dari variabel kualitas pelayanan, keputusan pembelian tetap memiliki nilai sebesar 12.682 .

2. Variabel kualitas pelayanan memiliki nilai $t$ hitung lebih besar dari t tabel $(2.768>$ 1.984). Artinya kualitas pelayanan terbukti berpengaruh positif terhadap keputusan 
pembelian. Dengan tafsiran, jika kualitas pelayanan meningkat sebesar satu-satuan maka keputusan pembelian akan meningkat sebesar 0.258.

3. Variabel kualitas pelayanan memiliki nilai signifikan lebih kecil dari 0,05 $(0.007<$ 0,05). Artinya kualitas pelayanan berpengaruh signifikan terhadap keputusan pembelian. Dengan tafsiran, variabel kualitas pelayanan mampu menjelaskan keputusan pembelian dengan baik dengan koefisien regresi sebesar 0.258.

Tabel 4.6. Uji Simultan (Uji F)

\begin{tabular}{|l|r|r|r|r|r|}
\hline Model & Sum of Squares & df & Mean Square & F & Sig. \\
\hline 1 Regression & 967.263 & 2 & 483.631 & 45.311 & $.000^{\mathrm{a}}$ \\
Residual & 1014.003 & 95 & 10.674 & & \\
Total & 1981.265 & 97 & & & \\
\hline
\end{tabular}
a. Predictors: (Constant), Kualitas Pelayanan, Harga
b. Dependent Variable: Keputusan Pembelian

Sumber: Hasil Olah Data SPSS 22, 2017

Berdasarkan tabel di atas, diketahui bahwa nilai $\mathbf{F}$ hitung sebesar $\mathbf{4 5 . 3 1 1}$ lebih besar dari F tabel sebesar 3,09, maka dapat disimpulkan bahwa secara bersamasama variabel harga dan kualitas pelayanan berpengaruh positif dan signifikan terhadap keputusan pembelian.

\section{G. Kesimpulan}

Berdasarkan hasil analisis dan pembahasan maka dapat diambil kesimpulan sebagai berikut :

1. Hasil analisis regresi membuktikan, strategi harga terbukti berpengaruh positif dan signifikan terhadap keputusan pembelian sebesar 0.510 dan t hitung 5.484 .

2. Hasil analisis regresi membuktikan, kualitas pelayanan berpengaruh positif dan signifikan terhadap keputusan pembelian sebesar 0.258 dan t hitung 2.768.

3. Hasil analisis regresi membuktikan, strategi harga dan kualitas pelayanan secara bersama-sama terbukti berpengaruh positif dan signifikan terhadap keputusan pembelian dengan kontribusi sebesar $47,7 \%$ sedangkan sisanya sebesar $52,3 \%$ dijelaskan oleh variabel lain di luar penelitian ini. 


\section{H. Daftar Pustaka}

Dharmesta dan Irawan, 2005, Manajemen Pemasaran Modern, Edisi Kedua, Liberty, Yogyakarta.

Handoko, T. Hani, 2008,Manajemen Personalia Sumber Daya Manusia, EdisiKedua,BPFE, Yogyakarta.

Hurriyati, Ratih, 2008, Bauran Pemasaran dan Loyalitas Konsumen, Alfabeta, Bandung.

Kotler, Philip, 2005, Manajemen Pemasaran, Bumi Aksara, Jakarta.

, and K.L. Keller, 2009, Manajemen Pemasaran. Edisi Ke 14. Jilid Ke 1, Erlangga. Jakarta.

Riduwan dan Engkos Achmad Kuncoro, 2011, Cara Menggunakan dan Memaknai Path Analysis (Analisis Jalur), Edisi Revisi, Cetakan Ketiga. Alfabeta, Bandung.

Sugiyono, 2012, Metode Penelitian Bisnis, Alfabeta, Bandung.

Swastha, Basu dan Irawan, 2007, Manajemen Pemasaran Modern Analisis Perilaku Konsumen, Liberty, Yogyakarta. 